\title{
Open innovation: on the influence of internal and external collaboration on degree of newness
}

\author{
Astrid Heidemann Lassen \\ Center for Industrial Production, Aalborg University, Aalborg, Denmark, and \\ Bjørge Timenes Laugen \\ Sub Sea Services, Stavanger, Norway
}

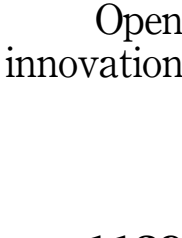

1129

Received 29 October 2015 Revised 23 October 2016 Accepted 3 November 2016

\begin{abstract}
Purpose - The purpose of this paper is to test the effect of internal and external collaboration on the degree of newness (incremental/radical) in innovation projects. This adds to the understanding of the particular patterns of open innovation $(\mathrm{OI})$ and what characterizes the innovation emerging through this approach.

Design/methodology/approach - Tests are performed on the effect of internal and external collaboration on the degree of newness (incremental/radical) in innovation projects. This adds to the understanding of the particular patterns of $\mathrm{OI}$ and what characterizes the innovation emerging through this approach. The empirical analysis is based on a data set including responses from 512 Danish engineers.

Findings - The results show that external collaboration has significantly different effects on the degree of newness depending on the type of external partners involved, and they also show that radical innovation output is positively related to involving the $\mathrm{R} \& \mathrm{D}$ department (internal) and universities (external involvement) and negatively related to involving suppliers.

Originality/value - The results provide a more detailed understanding of how different OI patterns affect the development of incremental vs radical innovation in existing organizations. In particular, three findings add new insights into how OI affects innovation to reach the highest degree of newness: high importance of collaboration with external partners with distinct interests and skills; low reliance on existing customers and suppliers for the development of radical innovation; and narrow and focused internal involvement rather than broad internal involvement.
\end{abstract}

Keywords Internal and external collaboration, Open innovation, Incremental and radical innovation, Survey Paper type Research paper

\section{Introduction}

Open innovation (OI) has been demonstrated to affect a firm's innovative output positively by providing three substantive benefits: knowledge sharing, risk reduction, and speed of development. Through collaboration, each partner can potentially obtain a greater amount of knowledge from the project than would have been possible from a comparable investment made independently (Berg et al., 1982). Resource sharing between two or more organizations is one of the ways of reducing the cost of product development and decreasing the risk of failure (Hagedoorn, 1993). Further, collaboration also permits firms to react swiftly to market needs through increased speed of development and heightened responsiveness to customer needs.

The promise of such substantial benefits has driven the domain of OI forward, and since the early 2000s, a substantial body of literature has developed (e.g. Chesbrough, 2003; Laursen and Salter, 2006; Grimpe and Sofka, 2009; Garriga et al., 2013). Many advances have been made in terms of understanding the process of including external knowledge in internal innovation projects as well as exploiting internal knowledge through external

(C) Astrid Heidemann Lassen, Bjørge Timenes Laugen. Published by Emerald Publishing Limited. This article is published under the Creative Commons Attribution (CC BY 4.0) licence. Anyone may reproduce, distribute, translate and create derivative works of this article (for both commercial and non-commercial purposes), subject to full attribution to the original publication and authors. The full terms of this licence may be seen at http://creativecommons.org/licences/by/4.0/legalcode

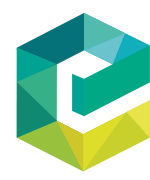

Business Process Management Journal pp. $1129-1143$ phing Limited

Emerald Publishing Limited 
BPMJ

23,6

1130

partners. In many such studies, the effect on innovation has been measured in terms of an increase in the amount of development projects, in the sales generated based on new products, or in the frequency of launching new products, all of which provide important insights into how OI affects a firm's development activities.

However, one major discussion remains less explored in the innovation management literature: how openness affects incremental vs radical innovation. From innovation management, it is clear that incremental and radical innovation differ substantially in nature, process, and consequences (e.g. significant changes in the trajectory of the firm) (e.g. Leifer et al., 2000). This discussion departs in an understanding of the very nature of the innovation, which is related to degree of newness. The present paper expands on the above line of reasoning and contributes to this discussion by testing the effect of internal and external collaboration on the degree of newness (incremental/radical) in innovation projects. This adds to the understanding of the particular patterns of OI and what characterizes the innovation emerging through this approach.

\subsection{Innovation and collaboration}

This section further expands on the fundamental reasoning behind the OI paradigm and the gap in knowledge in relation to the degree of newness generated.

Historically, firms have organized R\&D internally and relied on outside contract research only for relatively simple functions or products (Mowery, 1983). Today, firms are executing nearly every step in the production process, from discovery to distribution, through some form of external collaboration. In particular, new market imperatives have led companies to move from vertically aligned operations (Hayes and Wheelwright, 1984) to horizontally aligned operations (Goshall and Bartlett, 1995), which has consequently shifted competition from the level of single firms to that of networks of companies. These various types of inter-firm alliances take on many forms, ranging from R\&D partnerships to equity joint ventures to collaborative manufacturing.

An array of theories on interaction between companies has developed in recent decades (Grandori and Soda, 1995; Olivers and Ebers, 1998). Theoretical approaches studying inter-organizational relationships include the transaction cost approach (Coase, 1937; Williamson, 1985), resource dependency approach (Pfeffer and Salancik, 1978), network approach (Håkansson, 1989; Håkansson and Snehota, 1995; Ford et al., 2003), and organizational learning approach (Levitt and March, 1988; Cohen and Levinthal, 1990). These theories attempt to explain, from different angles, how the boundaries of a firm are affected by the access to resources and competencies needed to manufacture its products and deliver its services. The most common rationales offered to explain the increase in collaboration involve a combination of risk sharing, obtaining access to new markets and technologies, and coupling complementary skills (Kogut, 1989; Kleinknecht and Reijnen, 1992; Hagedoorn, 1993; Mowery and Teece, 2008; Eisenhardt and Schoonhoven, 1996).

Overall, this has resulted in a substantial body of literature on the relationship between network and innovation. The principal focus has largely been on the adoption or diffusion of innovations based on network positions, strengths of ties (Granovetter, 1985), or from the human resource/social capital perspective. In this sense, primary emphasis is placed on the understanding of the collaboration, and innovation is used in a wider sense as the output variable.

Within the innovation management literature, the topic of collaboration has also been the subject of much interest. The link between innovation and collaboration is often emphasized and acknowledged as a source of competitive advantage (Argote and Ingram, 2000). Littler et al. (1995) argue that collaboration can affect a firm's innovative output positively by providing three substantive benefits: knowledge sharing, risk reduction, and speed of development. Through collaboration, each partner can potentially obtain a greater amount of knowledge from the project than would have been possible from a comparable investment made independently (Berg et al., 1982). Furthermore, resource sharing between two or more 
organizations is one of the ways of reducing the cost of product development and decreasing the risk of failure (Hagedoorn, 1993). In addition, Kent (1991) argues that collaboration also permits firms to react swiftly to market needs through increased speed of development and heightened responsiveness to customer needs.

This link is becoming progressively more important as fast-changing market conditions heighten the need for organizations to sustain continuous innovative activities. This need also lays the foundation for Chesbrough's (2003) observation that a shift from closed innovation principles to OI principles is essential for business survival. Discussing the importance of integrating different sources of knowledge in the innovation process, Chesbrough (2003) notes that it is no longer sufficient to focus on generating innovation in a closed innovation system existing solely within the boundaries of a firm, but that innovation should take place in an OI system in collaboration with sources from the external environment. This observation has interesting consequences for the way in which innovation should be perceived, as it highlights the importance of considering the application of an inter-firm perspective rather than merely an intra-firm perspective for creating innovation.

The closed innovation system is based on the premise that firms can develop a competitive advantage by building in-house research and development competencies, which effectively enable the development and commercialization of new products, processes, or services. Clear organizational boundaries enable the careful protection of ideas. The business development strategy is normally based on clearly defined objectives and justifiable product/market trajectories, and new ideas are screened to fit the organizational psychology and culture.

In contrast to this, and in accordance with the dynamic capability view of the firm (Teece et al., 1997; Zott, 2003), an OI system considers the firm essentially as a knowledge processing and utilizing entity focusing on inter-firm performance. Openness to using external sources of information and ideas in the firm's innovation processes and interactions between different partners is considered to be of great importance both in order to explore and to build up new capabilities (von Hippel, 1988; Chesbrough, 2003). In particular, the organizational capabilities of sensing subtle signals and seizing opportunities (Teece, 2000) are highlighted as essential contributions to innovative performance and long-term competitiveness. This perspective is consistent with research that highlights the importance of horizontal and vertical relationships as sources of innovation (Pavitt, 1984; von Hippel, 1988). Today, the benefits of external collaboration (customers, suppliers, universities, and others actors in the innovation systems) for innovative outcomes are widely acknowledged (Powell et al., 1996; Ahuja, 2000; Belderbos et al., 2004; Cassiman and Veugelers, 2002). Thus, most research on OI takes the positive benefits of external collaboration for granted and instead focuses attention on researching, for example, the complex managerial issues related to managing the external knowledge inflows in innovation projects (e.g. Katila and Ahuja, 2002; Lassen, 2015).

However, it remains unclear whether this positive relationship can automatically be taken for granted, as the research on realized performance effects seems ambiguous at best (Gassmann et al., 2010). Several empirical studies have shown that increased openness is followed by better performance, thus validating the benefits of involving external partners in OI processes (e.g. Katila and Ahuja, 2002; Fleming and Sorenson, 2004; Laursen and Salter, 2006; Grimpe and Sofka, 2009; Garriga et al., 2013). However, considering the measures of innovation performance used in such empirical studies, we find that the most common measures often refer to innovation and innovativeness in a somewhat non-dichotomous fashion. The common variables used are, for example, R\&D expenditures (Hagedoorn and Cloodt, 2003; Laursen and Salter, 2006), number of patents (Ernst, 2001), increase in market share (Chesbrough, 2007), percentage of sales of products new to the firm in the previous three years (Laursen and Salter, 2014), and the frequency of new product introduction (Katila and Ahuja, 2002). While such measures reveal important knowledge 
BPMJ

23,6

1132

about the effect of external collaboration on firm performance, they do not discriminate between incremental and radical innovation and therefore lack a direct focus on the nature of the innovation itself.

Incremental innovation is critical to sustaining and enhancing shares in mainstream markets (Baden-Fuller and Pitt, 1996) and focuses on improving/expanding existing products and services (Bessant, 2003). Measures of innovation in terms of the number of new products launched, frequency of new product launch, and even sales of products new to the firm (measured by new product item number) are important, but they will often capture the effects created through incremental innovation.

In contrast, radical innovation serves as the basis for future technologies, products, services, and industries (Christensen, 1997; Hamel, 2000; Abetti, 2000). Terms such as "disruptive," "radical," "non-linear," "discontinuous," "breakthrough," and "paradigm-shifting" have all been used to describe what is in essence breaking away from the customary, creating entirely new possibilities for growth. Radical innovation requires organizations to move into unknown territory and experiment with new processes that largely elude systemization. Because radical innovations face an inherently more uncertain development process, more complex customer adoption processes, and by extension, a more difficult marketing process, this type of innovation requires a different skill set for a firm than does incremental innovation (Leifer et al., 2000; O'Connor and Ayers, 2005; Lassen et al., 2006; Kohlborn et al. 2014).

Research has demonstrated that radical innovation is much less frequent than incremental innovation, only accounting for approximately 5-10 percent of innovations (e.g. Henderson and Clark, 1990; Stringer, 2000; Lassen and Laugen, 2011). However, radical innovation has been demonstrated to affect the long-term performance of companies, and it is considered to be highly important as a primary driver of change, renewal, and economic growth. A variety of empirical studies have shown that the degree of newness of an innovation strongly influences the factors that shape innovative performance (Garcia and Calantone, 2002; Freeman and Soete, 1997; Tidd et al., 2001).

Hence, we argue that OI performance should also be viewed and discussed in light of the degree of newness created through the projects in question (Lassen, 2007). The degree of newness is here defined following Duguet (2006) and refers to how incremental/radical the innovation is.

\subsection{Research questions}

With this understanding of the differences between incremental and radical innovation in mind, interesting questions emerge regarding the degree of newness created through OI and if/how this differs from the degree of newness created through internal innovation efforts.

Such questions are researched and discussed in this study with the aim of extending and refining the OI framework. The questions are operationalized into the following two specific research questions for empirical research:

$R Q 1$. What is the influence of internal collaboration on the degree of newness?

$R Q 2$. What is the influence of external collaboration on the degree of newness?

The research questions use internal/external collaboration as the expression of openness and degree of newness as the expression of how incremental/radical the innovation is. Figure 1 displays the simplified research model we use to perform the analyses.

By addressing these questions, we are able to determine not only how the OI paradigm affects the degree of newness created but also to provide evidence on the particular patterns of collaboration which favor high degrees of newness. 
This section provides an overview of the empirical data that constitute the basis of the present research. This includes a data description, an explanation of how the applied variables are operationalized, and an account of the analytical methods employed.

\subsection{Data description and survey procedures}

A quantitative research methodology was applied for the empirical investigation of the relationships between types of collaboration and the degree of newness of innovation output. The data were collected in 2006, using a web-based survey sent to 3,000 engineers employed in privately owned companies in Denmark. We chose to address the survey to engineering professionals because of their potential involvement at the R\&D level as well as the management level. In addition, approaching a defined group of employees (engineers) reduces some of the variance in factors, such as education level and tasks, that one could expect if employees from a larger set of disciplines were surveyed.

The survey was designed following a tailor-design approach (Dillman, 2000) to spark the interest of the respondents, insuring both informed answers and a high response rate. The survey consisted of 32 closed-ended questions, each with several sub-questions. Most questions were built on five-item Likert scales. For all questions, the possibility of adding comments and further explanations was also provided.

The survey was initially pilot-tested on 45 engineers undertaking an executive MBA on technology management, and in addition to filling out the survey the respondents were asked to provide detailed comments on the structure, logic, readability, and content of the survey. The goal of the pilot study was to determine whether the proposed questionnaire and procedures were adequate for the large study.

Upon consideration of the results of the pilot test, the survey was disseminated to a larger sample of 3,000 engineers. The sample was selected from IDA's (the Danish Society of Engineers) database on members. The engineers included in the sample were employed in a wide range of sectors, such as services, batch manufacturing, and the food and processing industries. Through such a cross-sectional sampling, indications of general patterns were observed rather than indications limited to one particular sector.

The survey was disseminated to all 3,000 individuals using personal e-mails, with each respondent assigned with a unique personal identification number (PID\#). This allowed for detailed tracking of the progress of responses. The number of bounced e-mails was very low, as the e-mail addresses were provided from the IDA member database, which is updated on a regular basis. Thus, the procedure for handling bounced e-mails primarily dealt with server access problems, which are normally an issue of temporary downtime, and this was solved by re-sending the e-mail a few hours later.

According to Dillman (2000), the procedure for handling respondent inquiries, following the dissemination of the survey, also has a significant influence on the success of the survey. Thus, it was decided to direct all questions to one person, who was placed in charge of answering all inquiries in detail. The inquiries included questions such as how the e-mail

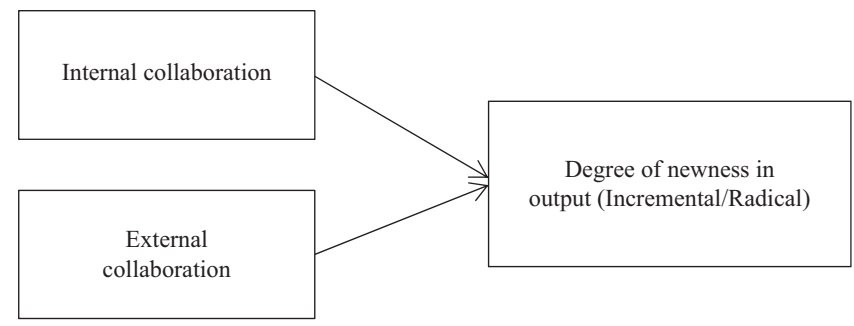

Figure 1 .

Simplified research model 
BPMJ

23,6

1134

addresses were acquired, how specific questions should be interpreted, and whether short extensions on the deadline were possible and prompted discussion on the general topics covered in the survey in more detail. The impression given was that the detailed answering procedure for all inquiries increased the number of responses given.

The first dissemination of the survey was followed up by one reminder when the monitoring of the incoming responses showed a consistent slow-down.

The survey resulted in a total of 803 responses, for a total response rate of 26 percent.

The questionnaire initially required the respondents to indicate whether they had participated in a product, process, or technology development project in the company in which they were employed at the time. Of the 803 responses, 512 (17 percent of the total sample) indicated that they had participated in such a development project, and these formed the population for the present study.

All responses to the questionnaire were based on the respondents' experiences with the most recent development project in which they participated. The respondents' participation included all phases of the particular development project, from ideation to implementation.

Although in general it is difficult to establish a systematic justification of what to consider as an acceptable response rate (Roth and BeVier, 1998), an applied response rate of 17 percent for a large-scale web-based survey such as this one provides a satisfactory basis for drawing sound conclusions on the research questions. Table I presents descriptive statistics regarding the respondents in the sample.

To test for non-response bias, the characteristics of the 512 used responses were compared with those from the overall sample of 3,000 members of the IDA database to whom the survey was distributed. No significant differences $(p>0.05)$ were found between the two samples in terms of the ages (average 44.4 years in the IDA sample, vs 43.6 years in the study sample) or genders (12 percent female in the IDA sample, vs 9 percent in ours) of the respondents. Hence, the sample in this study appears to represent the larger population of Danish engineers.

\subsection{Operationalization of variables}

Collaboration. Six types of organizational sources were used: customers, competitors, suppliers, partners, research institutions, and networks. Following Laursen and Salter (2004, 2006), this measure has been used in numerous studies on OI to proxy for firm-level openness (see e.g. Grimpe and Sofka, 2009; Lee et al., 2010; Leiponen and Helfat, 2010; Garriga et al., 2013; Love et al., 2014).

The patterns of collaboration were analyzed in two steps: based on the type/extent of internal collaboration between departments/functions (manufacturing, R\&D, sales/marketing and management), and based on the type/extent of external collaboration (customers,

\begin{tabular}{lrlr}
\hline Individual-level variables & $n$ & Firm-level variables & $n$ \\
\hline Gender & & Number of employees & \\
Female & 42 & $1-50$ & 91 \\
Male & 457 & $51-300$ & 133 \\
& & $301+$ & 264 \\
Level of education & & Company age (years) & \\
PhD & 2 & $0-5$ & 46 \\
MSc & 199 & $6-10$ & 36 \\
BSc & 304 & $11-15$ & 72 \\
Other & 6 & $16-30$ & 283 \\
& & $30+$ &
\end{tabular}

Table I.

Description of the respondents in the sample 
competitors, suppliers, partners, research institutions, and networks). The respondents were asked to indicate on a 1 (not at all) to 5 (to a very high extent) Likert scale the extent to which the internal and external actors were involved in the innovation projects.

Degree of newness. Innovation was measured in terms of the degree of newness of the output in the last development project in which each respondent indicated that he or she had been involved. The respondents were asked to indicate whether this project was characterized as a product, process, or technological development project. In addition, they were asked to indicate, for each of the types, the degree of newness of the respective project. The scale, which is based on the work by Garcia and Calantone (2002), includes four categories of degree of newness, ranging from (1) new to the respondent (2) new to the firm (3) new to the market, to (4) new to the world. In the analytical stage, a refined variable was devised indicating the average newness of all three types of innovation projects. The reliability of the new scale was satisfactory (Cronbach's $\alpha=0.554$ ).

Contingencies. In the analytical stage we controlled for company age and size. The respondents were asked to indicate the age of the organization on the following scale: 0-5 years, 6-10 years, 11-15 years, $16-30$ years, and 31 or more years. To measure organizational size, the respondents were asked to indicate the number of employees in the company. We used the following scale: $0-10,11-50,51-100,101-300$, and 301 or more.

\subsection{Analytical method}

To investigate the relationships between the variables, we performed regression analyses using SPSS 15. The degree of newness of the innovation projects was used as a dependent variable. The type/extent of internal and external collaboration were used as independent variables. In addition, the analyses controlled for the direct effects of company size and age on the dependent variable.

\section{Results and analysis}

This section presents the results of the analyses. The findings are consecutively described and discussed in order to address each sub-question separately, providing evidence for the general research question of the paper.

\subsection{Collaboration in innovation projects}

First, a joint analysis of the degree of involvement in the innovation project of both internal and external partners is illustrated.

Of the internal functions within organizations, R\&D was most directly involved in the innovation projects, followed by management, as indicated in Table II. Subsequently, production and sales/marketing were involved to an approximately similar degree.

In terms of external involvement, customers and suppliers were most involved, while competitors, universities, and networks were involved to a very low extent. The involvement of internal functions was higher than the involvement of external actors.

\subsection{The influence of internal collaboration on degree of newness}

Second, we analyzed the influence of internal and external collaboration on the degree of newness created through the projects. The result of this analysis is displayed in Table III.

We found a positive and significant relationship between the involvement of the R\&D function and the degree of newness of the innovation project $(\beta=0.182, p<0.01)$. This indicates that projects in which the R\&D function was involved had a more radical output. We did not find a significant relationship between the involvement of the other internal functions and the degree of newness of the projects. 


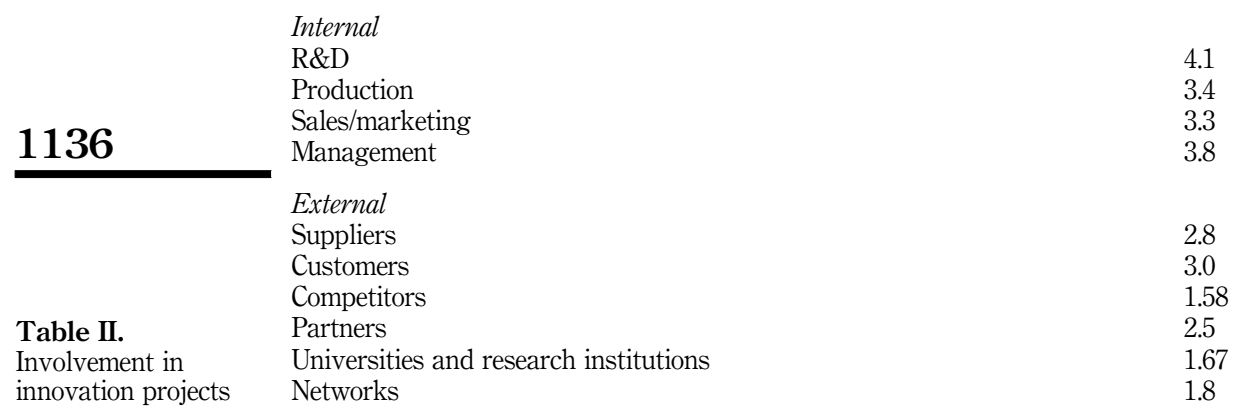

Table III.

Regression analysis of innovation output, internal and external involvement, and control variables

\begin{tabular}{lccc}
\hline & Dependent variable: degree of newness of output in innovation projects \\
& $\beta$ & $t$ & Sig. \\
\hline Constant & & 11.674 & 0.000 \\
R\&D & 0.182 & 3.258 & 0.001 \\
Production & 0.005 & 0.083 & 0.934 \\
Sales/marketing & -0.060 & -0.988 & 0.324 \\
Management & -0.049 & -0.821 & 0.412 \\
Suppliers & -0.200 & -3.503 & 0.001 \\
Customers & -0.042 & -0.723 & 0.470 \\
Competitors & 0.028 & 0.502 & 0.616 \\
Partners & 0.054 & 0.894 & 0.372 \\
Universities and research institutions & 0.156 & 2.454 & 0.015 \\
Networks & 0.034 & 0.534 & 0.594 \\
Company age & -0.171 & -2.353 & 0.019 \\
Employees & 0.082 & 1.124 & 0.262 \\
Adjusted $R^{2}$ & 0.096 & & \\
$F$ & 3.800 & & \\
Sig. & 0.000 & & \\
& & & \\
\end{tabular}

These findings are hardly surprising. R\&D is normally active in the development of new technologies, which will add to the novelty of products and processes. This, again, is associated with a higher degree of newness of the projects. The lack of a relationship between newness and the involvement of manufacturing could indicate that the companies understand the importance of integrating manufacturing in all types of innovation projects, not only in those characterized by a high degree of newness. The insignificant relationship between newness and the involvement of sales/marketing indicates that the companies use market input in all types of innovation projects.

\subsection{The influence of external collaboration on degree of newness}

Considering the external collaboration, innovation projects that involved suppliers to a high degree seemed to have lower degrees of newness of the output $(\beta=-0.200, p<0.01)$. In contrast, projects that involved universities had higher degrees of newness of the project output $(\beta=0.156, p<0.05)$. 
The negative relationship between newness and the involvement of suppliers suggests that suppliers are primarily involved in incremental innovation projects. This could indicate that suppliers can primarily contribute with knowledge within the areas already known to the company, and to a minor extent with knowledge that is radically new.

The positive relationship between newness and the involvement of universities might indicate that companies search for research-based knowledge when they are developing radical projects. As indicated in Table I, the overall involvement of universities was low, but the findings suggest that industry/university collaboration is valuable in terms of a higher degree of newness of the innovation projects.

The weak and insignificant relationships between newness and the involvement of competitors, partners, and networks could suggest that these actors are involved equally in both incremental and radical projects, albeit to a relatively low degree, as shown in Table I.

The involvement of customers does not seem to be related to the newness of innovation projects either. This could suggest that the customers are involved in all types of innovation projects. It could also indicate that existing customers are in general unable to provide ideas regarding radical and disruptive innovations. This is suggested by authors such as Christensen (1997), Bessant et al. (2005), and others, and it is pointed to as a limitation of the increasing focus on user innovation in research as well as on the policy level.

\subsection{Control variables}

The negative and significant relationship $(\beta=-0.171, p<0.05)$ between company age and newness suggests that older companies are less radically innovative than are younger firms. We found no significant relationship between newness and company size, which suggests that size does not determine the newness of the output in innovation projects.

\subsection{Internal and external involvement in innovation projects}

When the internal functions and external actors are grouped so as to represent broad internal and external collaboration, respectively, the analysis presents a picture that differs somewhat from the results achieved when the functions and actors are analyzed separately. This is reflected in Table IV.

Broad internal involvement was significantly and negatively related to the newness of innovation projects $(\beta=-0.137, p<0.05)$. This is somewhat surprising, considering the relatively strong positive effect from the involvement of R\&D on newness. An explanation of this could be that when several different internal functions are involved in innovation projects, compromises might have to be reached between the different interests, which may lead to a lower degree of newness of the project to a level on which all can agree. Although the analyses here cannot claim causality, the result of broad internal involvement seems to be a more incremental type of innovation.

\begin{tabular}{|c|c|c|c|}
\hline & \multicolumn{3}{|c|}{ Dependent variable: degree of newness of output in innovation projects } \\
\hline Constant & & 23.271 & 0.000 \\
\hline Sum internal collaboration & -0.137 & -2.566 & 0.011 \\
\hline Sum external collaboration & 0.070 & 1.301 & 0.194 \\
\hline Adjusted $R^{2}$ & 0.010 & & \\
\hline$F$ & 3.294 & & \\
\hline Sig. & 0.038 & & \\
\hline
\end{tabular}

Table IV. Regression analysis of innovation output, internal and external involvement 
BPMJ 23,6

By contrast, we found no such indication of the broad involvement of external actors ( $\beta=0.070$, Sig. $>0.1)$. The findings show a subtle and insignificant tendency toward more radical output from innovation projects when a broad number of external actors are involved. This could indicate that the broad involvement of external actors can result in all types of innovations, from incremental to radical.

\section{Discussion and conclusions}

Through empirical analysis, this paper has provided a more detailed understanding of how different OI patterns affect the development of incremental vs radical innovation in existing organizations. In this section, we discuss the results more broadly in relation to how they support and expand on the knowledge of OI.

The first research question addressed the influence of internal collaboration on the degree of newness created. Here the results show that broad internal involvement is significantly and negatively related to the newness of innovation projects. This supports Chesbrough's (2003) argument that a closed innovation system based solely on the use of internal competencies is inadequate for developing a significant competitive advantage in today's markets. These results support and extend Chesbrough's argumentation of the inefficiency of the closed innovation paradigm by also demonstrating that the effect generated through this approach in terms of newness is low. An explanation for this could be that developing multiple, broad competencies and/or maintaining them in the face of rapid technological changes is difficult for firms, and thus the efforts made by departments that primarily focus on existing competencies or existing market needs will significantly influence innovation projects in an incremental direction if involved to a large extent in the innovation project.

In reply to the second research question, it is found that a high degree of supplier involvement is associated with a lower degree of newness of innovation projects, that the involvement of customers has no significant influence on the degree of newness of projects, and that a high degree of involvement of universities is associated with a high degree of newness of projects. This has important implications.

The result supports the stream of arguments suggesting that collaboration with external partners who have similar wishes, technological knowledge, and/or market insight may indeed lead to innovative activity, but this innovative activity will most likely not be radical in the sense of departing from the customary, breaking with the existing patterns, or introducing radically new products and/or technologies. This has interesting implications for the extensive focus on user-driven innovation (a subset of $\mathrm{OI}$ ), as the impact hereof, in terms of degree of newness, will be of a more incremental nature.

Following this argumentation, the results thus pinpoint that when entering into an OI project with the intent of creating something radically innovative, not only the complementarity of the partners but also the essential differences are important selection criteria to consider. This is illustrated through the identification of a number of firms collaborating with universities on innovation projects and the positive relationship this has on degree of newness. Universities differ on a range of parameters, such as their primary interests and short- vs long-term perspectives.

However, the empirical analysis also suggests that the development of radical innovation (i.e. a high degree of newness) is not solely dependent on high external involvement and collaboration between different external actors. It is also dependent on involvement and collaboration among functional departments and people. In particular, the development of radical innovation is still highly dependent on the involvement of the internal R\&D function. This suggests that while openness to external collaboration is increasingly important, the lead of the project must still reside internally in the organization in order to create a focus in the development of radical innovation. The loss of direct control of one company 
over the development process is often mentioned as a risk in connection with collaboration (Håkansson, 1989). It may well be of major importance to consider this aspect when developing radical innovation, which involves a more non-linear and discontinuous process per se. Maintaining focused internal competence when driving the OI process will support the creation of a certain level of stability in an otherwise potentially chaotic process. This means that internal collaboration is an important prerequisite for the ability to collaborate efficiently with external partners, and thus to absorb and exploit the useful competencies of other firms and thereby enhance the firm's own knowledge base and innovation performance.

In conclusion, these results have provided insight into the particular patterns of collaboration that impact the degree of innovation created. In particular, the results emphasize the following:

- high importance of collaboration with external partners with distinct interests and skills;

- low reliance on existing customers and suppliers for the development of radical innovation; and

- narrow and focused internal involvement rather than broad internal involvement.

The results of this research are valuable for their insight into the effect of $\mathrm{OI}$, as they refine and expand existing knowledge, particularly the innovation effects of the open vs closed innovation paradigms (Chesbrough, 2003). Additionally, this more detailed understanding of the collaboration patterns involved in innovation will be of managerial interest, as it provides insights into how the collaboration strategy of an organization should be constructed in order to best facilitate an environment conducive to highly radical innovation.

\subsection{Implications for managers}

Although the academic concept of OI is fairly new, the broad involvement of internal and external actors in the innovation process is not. Managers already understand that innovation can occur both through relying on internal resources and departments as well as by relying on partners outside the organization. The difficulty for managers, however, is determining an optimal balance between different actors in the various phases of the innovation process. The findings of this study provide insights as to how the involvement of various actors influences the degree of newness of the output of innovation projects. If the aim of an innovation project is to develop a process or product that is radically different from what is normal in the industry, companies should involve external actors and select research institutions and universities over customers and suppliers. There are several examples of industry-university collaborations that have led to radically new technologies or processes. Several radical innovations within the aviation, med-tech, semiconductor, and oil and gas industries have been developed and launched as a result of close interactions between companies and research institutions. To a large extent, the findings confirm this pattern. It is also found that internal R\&D departments are more involved in innovation projects with a radical output, while the involvement of other internal departments does not reveal a similar significant pattern.

These findings highlight the importance of managers designing a project team that is purposeful for the output of the innovation project: incremental-type innovation projects could/should involve production, sales/marketing, and management internally, and suppliers, customers, competitors, partners, and networks externally. Radical-type innovation projects could/should involve the internal R\&D department and universities/research institutions externally. Therefore, the results of this paper provide important input for the decision making and resource allocation processes in companies aiming to be more innovative. 
BPMJ

23,6

1140

\subsection{Limitations and further research}

While the contribution of this study is related to the content of the collaboration in innovation projects, the collaboration process is also of critical importance for managers. The data do not provide insights regarding how to manage the involvement of different actors in innovation projects. The interactions between internal and external actors - and how they should be managed - are likely to have a considerable influence on the success rates of innovation projects. In-depth case studies, preferably longitudinal, are necessary to develop further insights into this issue.

In addition, although not elaborated in this research, there are reasons to believe that there are configurational effects between the involvement of internal and external actors. Further investigations into the appropriate mixture or configuration of internal and external collaborations (and their effects) would be a natural extension of this research. Moreover, different actors may be involved differently in different phases of the innovation projects. Internal R\&D departments and universities might be heavily involved in the initiation phase and less so in later stages. Functions such as manufacturing might be heavily involved in the implementation phase of innovation projects. Further research could study the benefits and relevance of different types of involvement in different phases of innovation projects.

Finally, the findings indicate that company age has a negative relationship with the degree of newness of an innovation project. Although no relationship between size and degree of newness was found, future studies should elaborate on the influence of other contextual variables on innovation output. This could include factors such as industry type (e.g. manufacturing vs service firms), production process type (e.g. mass producers vs batch or one-off producers), position in the supply chain (e.g. B2B vs B2C), or technological complexity (e.g. high-tech vs low-tech firms). Investigating the impact of direct and indirect relationships between a range of contextual factors on the relationships between the type and degree of involvement and innovation output will contribute important knowledge to academia and industry and further elaborate the concept of OI.

\section{References}

Abetti, P.A. (2000), "Critical success factors for radical technological innovation: a five case study", Creativity and Innovation Management, Vol. 9 No. 4, pp. 208-221.

Ahuja, G. (2000), "Collaboration networks, structural holes, and innovation: a longitudinal study", Administrative Science Quarterly, Vol. 45 No. 3, pp. 425-455.

Argote, L. and Ingram, P. (2000), "Knowledge transfer: a basis for competitive advantage in firms", Organisational Behaviour and Human Decision Process, Vol. 82 No. 1, pp. 150-169.

Baden-Fuller, C. and Pitt, M. (1996), Strategic Innovation, Routledge, London.

Belderbos, M.C., Carree, M. and Lokshin, B. (2004), "Cooperative R\&D and firm performance", Research policy, Vol. 33 No. 10, pp. 1477-1492.

Berg, S.V., Duncan, J. and Friedman, P. (1982), Joint Strategies and Corporate Innovation, Oelgeschlager Gunn and Hain, Cambridge, MA.

Bessant, J. (2003), High-Involvement Innovation: Building and Sustaining Competitive Advantage through Continuous Change, John Wiley, West Sussex.

Bessant, J., Lamming, R., Noke, H. and Phillips, W. (2005), "Managing innovation beyond the steady state", Technovation, Vol. 25 No. 12, pp. 1366-1376.

Cassiman, B. and Veugelers, R. (2002), "Spillovers and R\&D cooperation: some empirical evidence", American Economic Review, Vol. 92 No. 4, pp. 1169-1184.

Chesbrough, H.W. (2003), "The logic of open innovation: managing intellectual property", California Management Review, Vol. 45 No. 3, pp. 33-58.

Chesbrough, H.W. (2007), "Why companies should have open business models", MIT Sloan Management Review, Vol. 48 No. 2, pp. 22-28. 
Christensen, C.M. (1997), The Innovator's Dilemma: When New Technologies Cause Great Firms to Fail, Harvard Business Scholl Press, Boston, MA.

Coase, R.H. (1937), "The nature of the firm, economica”, New Series, Vol. 4 No. 16, pp. 386-405.

Cohen, W.M. and Levinthal, D.A. (1990), "Absorptive capacity: a new perspective on learning and innovation”, Administrative Science Quarterly, Vol. 35 No. 1, pp. 128-152.

Dillman, D. (2000), Internet, Mail, and Mixed-Mode Surveys: The Tailored Design Method, 3rd ed., John Wiley, New Jersey, NJ.

Duguet, E. (2006), "Innovation height, spillovers and the growth at the firm level: evidence from French manufacturing", Economics of Innovation and New Technology, Vol. 15 Nos 4-5, pp. 415-442.

Eisenhardt, K. and Schoonhoven, C.B. (1996), "Strategic alliance formation in entrepreneurial firms: strategic needs and social opportunities for cooperation", Organization Science, Vol. 7 No. 7 , pp. 136-150.

Ernst, H. (2001), "Patent applications and subsequent changes of performance: evidence from time-series cross-section analyses on the firm level”, Research Policy, Vol. 30, No. 1 pp. 143-157.

Fleming, L. and Sorenson, O. (2004), "Science as a map in technological search", Strategic Management Journal, Vol. 25, Nos 8-9 pp. 909-928.

Ford, D., Gadde, L., Håkansson, H. and Snehota, I. (2003), Managing Business Relationships, John Wiley and Sons, Chichester.

Freeman, C. and Soete, L.L.G. (1997), The Economics of Industrial Innovation, Pinter, London.

Garcia, R. and Calantone, R. (2002), "A critical look at the technological innovation typology and innovativeness terminology: a literature review", The Journal of Product Innovation Management, Vol. 19 No. 2, pp. 110-132.

Garriga, H., von Krogh, G. and Spaeth, S. (2013), "How constraints and knowledge impact open innovation”, Strategic Management Journal, Vol. 34 No. 9, pp. 1134-1144.

Gassmann, O., Enkel, E. and Chesbrough, H. (2010), "The future of open innovation", R\&D Management, Vol. 40 No. 3, pp. 213-221.

Goshall, S. and Bartlett, C. (1995), "Changing the role of top management: beyond structure to processes", Harvard Business Review, Vol. 73 No. 1, pp. 86-96.

Grandori, A. and Soda, G. (1995), "Inter-firm networks: antecedents, mechanisms, and forms", Organization Studies, Vol. 16 No. 2, pp. 183-214.

Granovetter, M. (1985), "Economic action and social structure: the problem of embeddedness", American Journal of Sociology, Vol. 91 No. 3, pp. 481-510.

Grimpe, C. and Sofka, W. (2009), "Search patterns and absorptive capacity: low-and high-technology sectors in European countries", Research Policy, Vol. 38 No. 3, pp. 495-506.

Hagedoorn, J. (1993), "Understanding the rationale of strategic technology partnering: interorganizational modes of cooperation and sectoral differences", Strategic Management Journal, Vol. 14 No. 5, pp. 371-385.

Hagedoorn, J. and Cloodt, M. (2003), "Measuring innovative performance: is there an advantage in using multiple indicators?”, Research Policy, Vol. 32 No. 8, pp. 1365-1379.

Håkansson, H. (1989), Corporate Technological Behavior: Co-operation and Networks, Routledge, London.

Håkansson, H. and Snehota, I. (1995), Networks in Technological Development, Routledge, London.

Hamel, G. (2000), Leading the Revolution (e-book), HBS Press, New York, NY.

Hayes, R.H. and Wheelwright, S.C. (1984), Restoring Our Competitive Edge: Competing through Manufacturing, Wiley, New York, NY.

Henderson, R. and Clark, K.B. (1990), "Architectural innovation: the reconfiguration of existing product technologies and the failure of established firms", Administrative Science Quarterly, Vol. 35 No. 1, pp. 9-30. 
BPMJ

23,6

Katila, R. and Ahuja, G. (2002), "Something old, something new: a longitudinal study of search behavior and new product introduction”, Academy of Management Journal, Vol. 45 No. 8, pp. 1183-1194.

Kent, D.H. (1991), "Joint ventures vs. non-joint ventures: an empirical investigation", Strategic Management Journal, Vol. 12 No. 5, pp. 387-393.

Kleinknecht, A. and Reijnen, J.O.N. (1992), "Why do firms cooperate on R\&D? An empirical study", Research Policy, Vol. 21 No. 4, pp. 347-360.

Kogut, B. (1989), "The stability of joint ventures: reciprocity and competitive rivalry", Journal of Industrial Economics, Vol. 38 No. 2, pp. 183-198.

Kohlborn, T., Mueller, O., Poeppelbuss, J. and Roeglinger, M. (2014), "Interview with Michael Rosemann on ambidextrous business process management”, Business Process Management Journal, Vol. 20 No. 4, pp. 634-638.

Lassen, A.H. (2007), "Corporate entrepreneurship: towards an understanding of the importance of radical innovation in knowledge intensive firms", $\mathrm{PhD}$ dissertation, Center for Industrial Production, Aalborg University, Aalborg.

Lassen, A.H. (2015), "The back-end of user centred innovation”, Conference Proceedings, 16th International CINet Conference, Pursuing Innovation Leadership, Stockholm, September 13-15.

Lassen, A.H. and Laugen, B.T. (2011), The Innovative Engineer; On Practice, Problems and Potential, Center for Industrial Protection, Aalborg University, Aalborg.

Lassen, A.H., Gertsen, F. and Riis, J.O. (2006), "The nexus of innovation and radical innovation", Creativity and Innovation Management, Vol. 15 No. 4, pp. 359-372.

Laursen, K. and Salter, A. (2006), "Open for innovation: the role of openness in explaining innovation performance among UK manufacturing firms”, Strategic Management Journal, Vol. 27 No. 2, pp. 131-150.

Laursen, K. and Salter, A. (2014), "The paradox of openness: appropriability, external search and collaboration”, Research Policy, Vol. 43 No. 5, pp. 867-878.

Laursen, K. and Salter, A.J. (2004), "Searching low and high: why do firms cite universities as a source of innovation?", Research Policy, Vol. 33 No. 8, pp. 1201-1215.

Lee, S., Park, G., Yoon, B. and Park, J. (2010), "Open innovation in SMEs - an intermediated network model”, Research Policy, Vol. 39 No. 2, pp. 290-300.

Leifer, R., McDermott, C.M., O’Connor, G.C., Peters, L.S., Rice, M.P., Veryzer, R.W. and Rice, M. (2000), Radical Innovation. How Mature Companies can Outsmart Upstarts, Harvard Business School Press, Boston, MA.

Leiponen, A. and Helfat, C.E. (2010), "Innovation objectives, knowledge sources, and the benefits of breadth", Strategic Management Journal, Vol. 31 No. 2, pp. 224-236.

Levitt, B. and March, J. (1988), "Organizational learning”, American Review of Sociology, Vol. 14 No. 1, pp. 319-338.

Littler, D., Leverick, F. and Bruce, M. (1995), "Factors affecting the process of collaborative product development: a study of UK manufactures of information and communications technology products", Journal of Product Innovation Management, Vol. 2 No. 1, pp. 16-23.

Love, J.H., Roper, S. and Vahter, P. (2014), "Learning from openness: the dynamics of breadth in external innovation linkages", Strategic Management Journal, Vol. 35 No. 11, pp. 1703-1716.

Mowery, D.C. (1983), "The relationship between intrafirm and contractual forms of industrial research in American manufacturing, 1900-1940", Explorations in Economic History, Vol. 20 No. 4, pp. 351-374.

Mowery, D.C. and Teece, D.J. (2008), "Strategic alliances and industrial research", in Teece, D.J. (Ed.), The Transfer and Licensing of Know-How and Intellectual Property: Understanding the Multinational Enterprise in the Modern World, World Scientific Books, World Scientific Publishing.

O'Connor, G.C. and Ayers, A.D. (2005), "Building a radical innovation competency, industrial research institute, Inc", Journal of Research and Technology Management, Vol. 48 No. 1, pp. 309-334. 
Olivers, A.L. and Ebers, M. (1998), "Networking network studies: an analysis of conceptual configuration in the study of inter-organizational relationships", Organization Studies, Vol. 19 No. 4, pp. 549-583.

Pavitt, K.L.R. (1984), "Sectoral patterns of technical change: towards a taxonomy and a theory", Research Policy, Vol. 13 No. 6, pp. 343-373.

Pfeffer, J. and Salancik, G.R. (1978), The External Control of Organizations: A Resource-Dependence Perspective, Harper and Row, New York, NY.

Powell, W.W., Koput, K.W. and Smith-Doerr, L. (1996), "Interorganizational collaboration and the local of innovation: networks of learning in biotechnology", Administrative Science Quarterly, Vol. 41 No. 1, pp. 116-145.

Roth, P.L. and BeVier, C.A. (1998), "Response rates in HRM/OB survey research: norms and correlates, 1990-1994", Journal of Management, Vol. 24 No. 1, pp. 97-117.

Stringer, R. (2000), "How to manage radical innovation", California Management Review, Vol. 42 No. 4, pp. $70-88$.

Teece, D.J. (2000), "Strategies for managing knowledge assets: the role of firm structure and industrial context", Long Range Planning, Vol. 33 No. 1, pp. 35-54.

Teece, D.J., Pisano, G. and Shuen, A. (1997), "Dynamic capabilities and strategic management", Strategic Management Journal, Vol. 18 No. 7, pp. 509-533.

Tidd, J., Bessant, J. and Pavitt, K. (2001), Managing Innovation: Integrating Technological, Market and Organizational Change, 2nd ed., John Wiley \& Sons, Chichester.

von Hippel, E. (1988), The Sources of Innovation, Oxford University Press, New York, NY.

Williamson, O.E. (1985), The Economic Institutions of Capitalism: Firms, Markets, Relational Contracting, Free Press, New York, NY.

Zott, C. (2003), "Dynamic capabilities and the emergence of intra-industry differential firm performance: insights from a simulation study", Strategic Management Journal, Vol. 24 No. 2, pp. 97-125.

\section{Further reading}

Anderson, J.C. and Narus, J.A. (1990), "A model of distributor firm and manufacturer firm working partnerships”, Journal of Marketing, Vol. 54 No. 1, pp. 42-58.

Bleeker, J. and Ernst, D. (1991), "The way to win on cross-border alliances", Harvard Business Review, Vol. 69 No. 6, pp. 127-136.

Farr, C.M. and Fischer, W.A. (1992), "Managing international high technology cooperative projects", R\&D Management, Vol. 22 No. 1, pp. 55-67.

Fleming, L. and Sorenson, O. (2001), “Technology as a complex adaptive system: evidence from patent data", Research Policy, Vol. 30 No. 7, pp. 1019-1039.

Hamel, G., Doz, Y.L. and Prahalad, C.K. (1989), "Collaborate with your competitors and win", Harvard Business Review, Vol. 67 No. 1, pp. 133-139.

Leiponen, A. and Helfat, C.E. (2011), "Location, decentralization, and knowledge sources for innovation”, Organisation Science, Vol. 22 No. 3, pp. 641-658.

\section{Corresponding author}

Astrid Heidemann Lassen can be contacted at: ahl@business.aau.dk

For instructions on how to order reprints of this article, please visit our website:

www.emeraldgrouppublishing.com/licensing/reprints.htm

Or contact us for further details: permissions@emeraldinsight.com 